\title{
Functional autonomy of elderly women enrolled in a physical activity program
}

\author{
Fernanda de Noronha Ribeiro Daniel ${ }^{1}$, Rodrigo Gomes de Souza Vale ${ }^{2^{*}}$, Tania Santos Giani ${ }^{2}$, Silvia \\ Bacelar ${ }^{3}$ and Estélio Henrique Martin Dantas ${ }^{2}$
}

\begin{abstract}
${ }^{1}$ Programa de Pós-graduação Stricto Sensu em Ciência da Motricidade Humana, Universidade Castelo Branco, Rio de Janeiro, Rio de Janeiro, Brazil. ${ }^{2}$ Laboratório de Biociências da Motricidade Humana, Universidade Federal do Estado do Rio de Janeiro, Rua, Xavier Sigaud, 290/401, 22290-180, Praia Vermelha, Rio de Janeiro, Rio de Janeiro, Brazil. ${ }^{3}$ Instituto Nacional do Câncer, Rio de Janeiro, Rio de Janeiro, Brazil. *Author for correnpondence. E-mail: rodrigovale@globo.com
\end{abstract}

\begin{abstract}
The present study aimed to determine the effects of a physical activity program on the functional autonomy of elderly women. The sample was divided into an experimental group (EG; $\mathrm{n}=20 ; 68.51 \pm 5.02$ years; BMI $=27.01 \pm 4.35)$ submitted to a physical activity program, and a control group (CG; $\mathrm{n}=20 ; 67.01 \pm$ 3.51 years; $\mathrm{BMI}=26.71 \pm 5.74)$. Functional autonomy was assessed using tests from the GDLAM autonomy protocol: 10 meter walk test (10MW), rising from a sitting position (RSP), rising from a ventral decubitus position (RVDP), rising from a chair and moving around the house (RCMH) and putting on and taking off a t-shirt (PTT), after which the autonomy index (AI) was calculated. In the EG, ANOVA showed significant reductions in execution times for the RSP $(\Delta=-3.92 \mathrm{~s} ; \mathrm{p}=0.0001), \operatorname{RCMH}(\Delta=-9.61 \mathrm{~s} ; \mathrm{p}=0.0001), 10 \mathrm{MW}$ $(\Delta=-0.94 \mathrm{~s} ; \mathrm{p}=0.038)$ and RVDP $(\Delta=-1.15 \mathrm{~s} ; \mathrm{p}=0.036)$ tests, as well as the AI $(\Delta=-6.27 ; \mathrm{p}=0.0001)$. This was not observed in the CG. Intergroup comparisons demonstrated that execution times for the RSP $(\Delta \%=-36.63 ; \mathrm{p}=0.0001), \mathrm{RCMH}(\Delta \%=-20.27 ; \mathrm{p}=0.0001), 10 \mathrm{~mW}(\Delta \%=-12.54 ; \mathrm{p}=0.002)$ and RVDP $(\Delta \%=-25.10 ; \mathrm{p}=0.005)$ tests and the $\mathrm{AI}(\Delta \%=-21.37 ; \mathrm{p}=0.0001)$ of the EG were shorter than those of the CG. These results indicate that elderly subjects in the EG showed improved performance in activities of daily living after engaging in physical exercise.
\end{abstract}

Keywords: exercise, activities of daily living, aging.

\section{Autonomia funcional de mulheres idosas participantes de um programa de atividades físicas}

\begin{abstract}
RESUMO. O objetivo do estudo foi verificar os efeitos de um programa de atividade física sobre a autonomia funcional em mulheres idosas. A amostra foi distribuída em grupo experimental (GE; $\mathrm{n}=20 ; 68,51 \pm 5,02$ anos; $\mathrm{IMC}=27,01 \pm 4,35)$ submetido a um programa de atividade física e grupo controle $(\mathrm{GC} ; \mathrm{n}=20 ; 67,01 \pm 3,51$ anos; $\mathrm{IMC}=26,71 \pm 5,74)$. A autonomia funcional foi avaliada por meio dos testes do protocolo de autonomia GDLAM, caminhar $10 \mathrm{~m}$ (C10 m), levantar-se da posição sentada (LPS), levantar-se da posição decúbito ventral (LPDV), levantar-se da cadeira e locomover-se pela casa (LCLC) e vestir e tirar uma camiseta (VTC), e calculouse o índice de autonomia (IG). A ANOVA apresentou reduções significativas no tempo de execução nos testes LPS $(\Delta=-3,92 \mathrm{~s} ; \mathrm{p}=0,0001)$, LCLC $(\Delta=-9,61 \mathrm{~s} ; \mathrm{p}=0,0001)$, C10 $\mathrm{m}(\Delta=0,94 \mathrm{~s} ; \mathrm{p}=0,038)$ e LPDV $(\Delta=-1,15 \mathrm{~s} ; \mathrm{p}=0,036)$ e no IG $(\Delta=-6,27 ; \mathrm{p}=0,0001)$ no GE. O mesmo não ocorreu no GC. Nas comparações intergrupos, observou-se que as reduções nos tempos de execução dos testes LPS $(\Delta \%=-36,63 ; \mathrm{p}$ $=0,0001)$, LCLC $(\Delta \%=-20,27 ; \mathrm{p}=0,0001)$, C10 $\mathrm{m}(\Delta \%=-12,54 ; \mathrm{p}=0,002)$ e LPDV $(\Delta \%=-25,10 ; \mathrm{p}=$ $0,005)$ e no IG $(\Delta \%=-21,37 ; \mathrm{p}=0,0001)$ do GE foram menores que o GC. Estes resultados demonstram que as idosas do GE melhoraram o desempenho das atividades da vida diária com a realização de exercícios físicos.
\end{abstract}

Palavras-chave: exercício, atividades da vida diária, envelhecimento.

\section{Introduction}

Aging is a phenomenon involving biological, environmental and psychological factors (MORAN et al., 2007). It is associated to profound changes in organ and tissue cell and activity, as well as a possible reduction in efficiency of a number of physiological processes (GIBNEY et al., 2007).

All human systems undergo alterations as individuals age. The neuromuscular system exhibits a decrease in mass and muscle strength, reduced endurance and joint mobility (SACCO et al., 2008; VALE et al., 2009). These alterations may lead to chronic diseases, lower functional capacity, and loss of autonomy and independence (KRINSKI et al., 2008; LOJUDICE et al., 2008).

Physical activity, therefore, is an important tool for minimizing the harmful effects of aging by preserving and increasing physical aptitude (MAZO 
et al., 2007). Among the benefits promoted by regular physical exercise in elderly individuals are improved balance, coordination, strength levels and speed of movement. These factors contribute to increased functional autonomy, greater selfconfidence, and fewer falls (ASSUMPÇÃO et al., 2008), reflecting directly on the performance of activities of daily living (ADL) (SALMINEN et al., 2009; WIACEK et al., 2009; ZAK et al., 2009).

Thus, enhanced physical aptitude can result in individuals executing ADLs with less effort and prolong functional autonomy, allowing the aged to live independently and with dignity for as long as possible (DANTAS; VALE, 2004). In this connection, interventions designed to prevent the decline in functional capacity must promote better life conditions and decrease clinical institutionalizations of elderly individuals (BELLONI et al., 2008).

Considering that functional autonomy is related to sociodemographic factors, subjective perception, physical and mental health, independence in daily activities, social and family support and the use of health services (QUADROS et al., 2008; RAMOS, 2003), the elderly population of Piaui State are lacking in studies that investigate and characterize ADLs in these individuals. Thus, the aim of the present study was to determine the effects of a physical activity program on the functional autonomy of elderly women.

\section{Material and methods}

\section{Sample}

The study was initially composed of 232 elderly individuals enrolled in the Family Health Program (PSF08) in the district of Piçarreira I, in the municipality of Teresina, Piauí State, Brazil. Subjects were required to meet the following inclusion criteria: females; aged 60 years or older; independent in their ADLs; considered apt for medical assessment; and not having engaged in physical exercises for at least six months.

Subjects who presented with neurological alterations, vestibular system disorders and movement disorders related to cognitive decline were excluded from the study.

After the sampling process, 40 elderly women between 60 and 77 years of age were selected to take part in the study. Subjects were randomly allocated to an experimental group (EG; $\mathrm{n}=20 ; 68.51 \pm 5.02$ years; $\mathrm{BMI}=27.01 \pm 4.35)$, which participated in a physical activity program, and a control group (CG; $\mathrm{n}=20 ; 67.01 \pm 3.51$ years; $\mathrm{BMI}=26.71 \pm 5.74)$, who waited until the end of the study to undergo the same activity program.

All subjects gave their informed consent according to Resolution 196/96 of the National Health Council (BRASIL, 1996) and the Declaration of Helsinki (WMA, 2008). The study was approved by the Human Research Ethics Committee of Piaui State University (Uespi), Faculty of Medical Sciences (Facime), under protocol no. 89/08.

\section{Data collection procedures}

\section{Anthropometric assessment}

A Filizola mechanical scale with stadiometer, capacity of $150 \mathrm{~kg}$ and precision of $100 \mathrm{~g}$, was used to assess body mass and height, in accordance with the protocol proposed by the International Society for the Advancement of Kinanthropometry (MARFELL-JONES et al., 2006).

\section{Assessment of functional autonomy}

Functional autonomy was evaluated using the GDLAM autonomy protocol (DANTAS; VALE, 2004; VALE, 2005), composed of the following tests: 10 meter walk (10MW) (SPILÃ et al., 1996), rising from a sitting position (RSP) (GURALNIK et al., 1994), rising from a ventral decubitus position (RVDP) (ALEXANDER et al., 1997), rising from a chair and moving around the house (RCMH) (ANDREOTTI; OKUMA, 1999) and putting on and taking off a t-shirt (PTT) (DANTAS; VALE, 2004; VALE et al., 2006a). All tests were conducted during two attempts for each individual in a suitable environment, with a minimum interval of 5-min., in which the shorter time (seconds) was measured with a stopwatch (Casio, Brazil). Time elapsed from the start to end of the movement was considered the execution time. GDLAM autonomy index (AI) scores were then calculated (VALE, 2005), in which lowers scores represented better results, using the following formula:

$\mathrm{AI}=\frac{[(10 \mathrm{MW}+\mathrm{RPS}+\mathrm{RDVP}+\mathrm{PTT}) \times 2]+\mathrm{RCMH}}{4}$ where:

10MW, RSP, RVDP, PTT and RCMH = time recorded in seconds.

$\mathrm{AI}=$ GDLAM autonomy index scores

\section{Physical activity program}

The physical activity program (PAP) lasted 12 weeks, and consisted of twice-weekly $60 \mathrm{~min}$. sessions divided into the following five phases: a) 10 min. warm-up with joint mobility exercises and light stretching of the main joints; b) $20 \mathrm{~min}$. walk; 
c) 15 minutes of localized exercises for the major muscle groups (2 series of 15 repetitions: squats, elbow flexion and extension, shoulder horizontal flexion and extension, plantar flexion and abdominal crunches; d) maximum static stretching for $10 \mathrm{~min}$.; and e) neuromuscular relaxation for $5 \mathrm{~min}$. Exercise intensity was controlled by subjective perception of effort (BORG, 1982), maintaining a moderate level according to the Borg CR10 scale (level 2 to 3).

\section{Statistical analysis}

Data were presented as mean, standard deviation and percentage differences $(\Delta \%)$. The Shapiro-Wilk and Levene tests were used to check normality and homogeneity variances of sample data, respectively. Analysis of variance (two-way ANOVA) for intra and intergroup comparisons, followed by Tukey's post hoc test were applied to identify differences. A value of $\mathrm{p}<0.05$ was adopted for statistical significance. The SPSS 14.0 program was used for statistical analysis.

\section{Results}

Table 1 presents the results of intragroup comparisons of functional autonomy variables for the sample groups.

Table 1. Results of functional autonomy tests and the autonomy index for the experimental (EG) and control (CG) groups.

\begin{tabular}{ccccccc}
\hline & & Mean (pre) & SD & Mean (post) & SD & p-value \\
\hline EG & RSP & 10.70 & 2.71 & 6.78 & 1.05 & 0.000 \\
& RCMH & 47.42 & 7.05 & 37.81 & 7.09 & 0.000 \\
& PTT & 12.21 & 3.55 & 10.49 & 3.17 & 0.306 \\
& 10MW & 7.46 & 1.65 & 6.53 & 0.72 & 0.038 \\
& RVDP & 4.57 & 1.29 & 3.42 & 1.46 & 0.036 \\
& AI & 29.33 & 3.37 & 23.06 & 3.80 & 0.000 \\
CG & RSP & 11.05 & 2.13 & 11.30 & 1.99 & 0.987 \\
& RCMH & 47.59 & 5.28 & 47.71 & 5.03 & 0.998 \\
& PTT & 12.68 & 3.98 & 12.66 & 3.99 & 0.999 \\
& 10MW & 7.73 & 1.27 & 7.97 & 1.23 & 0.951 \\
& RVDP & 4.96 & 1.91 & 5.06 & 1.66 & 0.997 \\
& AI & 30.11 & 4.61 & 30.42 & 4.42 & 0.996
\end{tabular}

$10 \mathrm{MW}=10 \mathrm{~m}$ walk; $\mathrm{RSP}=$ rising from a sitting position; $\mathrm{RVDP}=$ rising from a ventral decubitus position; $\mathrm{PTT}=$ putting on and taking off a t-shirt; $\mathrm{RCMH}=$ rising from a chair and moving around the house; $\mathrm{AI}=$ GDLAM autonomy index scores; time recorded in seconds; $\mathrm{SD}=$ standard deviation; $\mathrm{EG}=$ experimental group; $\mathrm{CG}=$ control group; $\mathrm{p}<0.05=$ statistically significant difference.

Data in Table 1 show that the EG obtained significant reductions in execution time from the pre to post-test in the RSP, RCMH, C10MW and RVDP tests and the AI. This did not occur for the PTT test. The CG exhibited no significant intragroup alterations.

Figure 1 compares the results of intergroup functional autonomy using percentage difference $(\Delta \%)$. Percentage variations in the RSP $(\mathrm{p}=$ $0.0001)$, RCMH ( $p=0.0001), 10 \mathrm{MW}(\mathrm{p}=0.002)$, $\operatorname{RVDP}(p=0.005)$ tests and in AI $(p=0.0001)$ from the pre-test to the post-test in the EG displayed significant reductions $(p<0.05)$ when compared with the CG. The PTT test showed no significant alterations.

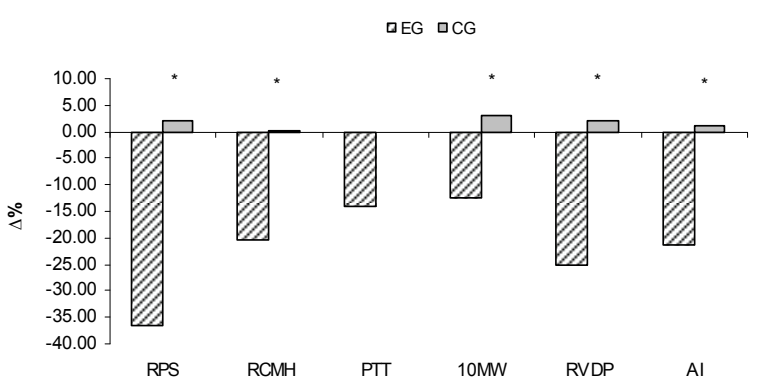

Figure 1. Percentage difference $(\Delta \%)$ in the functional autonomy tests and the GDLAM autonomy index between the experimental (EG) and control (CG) groups. ${ }^{\star} \mathrm{p}<0.05$; EG vs. CG. $\Delta \%=$ percentage difference.

\section{Discussion}

The findings of the present study showed a significant decrease in execution time on the 10MW, RSP, RCMH and RVDP tests and in the AI from the pre to post-test in the EG. Similar results were obtained in the CG. This suggests that the physical activity program (PAP) improved performance of ADLs in the active elderly.

Initial functional autonomy levels in the EG and CG were classified as weak for the 10MW $(>7.09 \mathrm{~s})$, RVDP ( $>4.40 \mathrm{~s})$, RCMH $(>43.00 \mathrm{~s})$ tests and the AI $(>27.42)$ and fair for RSP (11.19 - $9.55 \mathrm{~s})$ and PTT (13.14 - $11.62 \mathrm{~s})$ (VALE, 2005). Following the PAP, the levels of these tests improved as follows: fair (10MW: 7.09 - 6.34s; and RVDP: $4.40-3.30 \mathrm{~s}$ ), good (RCMH: 38.68 - 34.78 s; PTT: 11.61 - 10.14 s; and AI: 24.97 - 22.66) and very good (RSP: < 7.89 s) (VALE, 2005), suggesting enhanced performance of ADLs and resulting in more autonomy to perform specific movements in these tasks.

Guimarães et al. (2008) assessed functional autonomy using the GDLAM protocol, applying a physical activity program among elderly of both sexes enrolled in the Family Health Program. The difference in PAP between the two studies was water exercises, which were not used in this investigation, but the results of autonomy tests were similar.

These results are corroborated by Silva et al. (2009), who used resistance exercises with 40 elderly women and obtained significant improvements in GDLAM protocol autonomy tests in the four-week neurogenic phase, using moderate intensity $(50 \%$ 1RM), and in the 12-week intervention at high intensity $(90 \%$ 1RM). This suggests that the 
moderate intensity used in both studies led to better performance in ADLs, provided that the proposed exercises were systematized and directed. Thus, muscle strength is one of the factors that may be related to functional autonomy. This physical quality tends to remain at optimal levels during regular physical activity and up to approximately 12 weeks after the end of treatment, with progressive load stimuli from moderate to high intensity (RUBIO et al., 2007).

Pereira et al. (2007) found significant reductions in execution times in GDLAM protocol autonomy tests after 4-week and 20-week interventions, in relation to initial times. For the first phase, intensity of resistance exercise corresponded to $50 \%$ and in the second phase, the load was progressive (between 75 and $90 \%$ of 1RM). These findings reinforce those obtained in the present study, which used moderate intensity for different types of exercises and observed similar responses.

Rugelj (2009) evaluated balance and performance in the $10 \mathrm{~m}$ walk tests in elderly individuals performing 14 functional activities, observing that the experimental group significantly improved walking performance. Although the present study did not use functional exercises, results were similar for the walking activity, since it is the most executed ADL by the elderly. In this perspective, Isotalo et al. (2004) report that different types of body movements may create stimuli and distinct sensory information, provoking positive adaptations in the sensory-motor system. Thus, the variation of exercises used in the PAP of the present study may have produced the positive autonomy test results related to ADL performance in the EG.

Vale et al. (2006b) assessed elderly women submitted to resistance training for 16 weeks (4 weeks at $50 \%$ 1-RM and 12 weeks at $75-85 \%$ 1-RM), obtaining significant increases in muscle strength and range of joint motion, in addition to improved performance on the 10MW and RSP tests. However, the PAP applied in the present study did not use weight machines and obtained similar results in the autonomy tests with exercises performed using the body's own weight.

Functional autonomy has previously been analyzed using the GDLAM protocol in institutionalized elderly individuals (PEREIRA et al., 2003), with chronic obstructive pulmonary disease (BOECHAT et al., 2007) and with flexibility exercises (VALE et al., 2005). Results in the last study were similar to those obtained here.

\section{Conclusion}

The findings of the present study demonstrated reduced execution times on functional autonomy tests in the experimental group. This suggests that a regular physical activity program with systematized exercises of moderate intensity in the elderly may contribute to improved performance in ADLs such as walking more rapidly, sitting and rising with greater ease and dressing by themselves. Maintaining these activities contributes to improved functional autonomy in the aging population. Thus, this study opens perspectives for new investigations on systematized physical activity programs in family health programs (FHP) and their relationship with other variables, such as falls and hormonal changes associated to aging.

\section{References}

ALEXANDER, N. B.; ULBRICH, J.; RAHEJA, A.; CHANNER, D. Rising from the floors in older adults. Journal of the American Geriatrics Society, v. 45, n. 5, p. 564-569, 1997.

ANDREOTTI, R. A.; OKUMA, S. S. Validação de uma bateria de testes de atividades da vida diária para idosos fisicamente independentes. Revista Paulista de Educação Física, v. 13, n. 1, p. 46-66, 1999.

ASSUMPÇÃO, C. O.; PELLEGRINOTTI, I.; BARTOLOMEU NETO, J.; MONTEBELO, M. I. Controle da Intensidade progressiva de exercícios localizados em mulheres idosas por meio da percepção subjetiva de esforço (BORG). Revista de Educação Física, v. 19, n. 1, p. 33-39, 2008.

BELLONI, D.; ALBUQUERQUE, A. C.; RODRIGUES, T. O.; MAZINI FILHO, L.; SILVA, V. F. Estudo Comparativo entre a Autonomia Funcional de Mulheres idosas praticantes e não praticantes de hidroginástica. Revista de Educação Física, n. 140, p. 20-26, 2008.

BOECHAT, F.; VALE, R. G. S.; DANTAS, E. H. M. Evaluació de la autonomía funcional de personas mayores com EPOC mediante el protocolo GDLAM. Revista Española de Geriatría y Gerontología, v. 42, n. 4, p. 251-253, 2007.

BORG, G. A. V. Physiological bases of perceived exertion. Medicine and Science in Sports and Exercise, v. 14, n. 3, p. 377-387, 1982.

BRASIL. Ministério da Saúde. Resolução n. 196/96, de 10 de outubro de 1996. O Conselho Nacional de Saúde resolve aprovar diretrizes e normas regulamentadoras de pesquisas envolvendo seres humanos. Brasília, 1996.

DANTAS, E. H. M.; VALE, R. G. S. GDLAM's protocol of functional autonomy evaluation. Fitness and Performance Journal, v. 3, n. 3, p. 175-182, 2004.

GIBNEY, J.; HEALY, M-L.; SÖNKSEN, P. H. The growth hormone/insulin-like growth factor-i axis in 
exercise and sport. Endocrine Reviews, v. 28, n. 6, p. 603-624, 2007.

GUIMARÃES, A. C.; ROCHA, C. A. Q. C.; GOMES, A. L. M.; CADER, A. S.; DANTAS, E. H. M. Efeitos de um programa de atividade física sobre o nível de autonomia de idosos participantes do programa de saúde da família. Fitness and Performance Journal, v. 7, n. 1, p. 5-9, 2008.

GURALNIK, J. M.; SIMONSICK, E. M.; FERRUCI, L.; GLYNN, R. J.; BERKMAN, L. F.; BLAZER, D. G.; SCHERR, P. A.; WALLACE, R. B. A short physical performance battery assessing lower extremity function: association with self-reported disability and prediction of mortality and nursing home admission. The Journal of Gerontology, v. 49, n. 2, p. 85-94, 1994.

ISOTALO, E.; KAPOULA, Z.; FERET, P. H.; GAUCHONC, K.; ZAMFIRESCU, F.; GAGEY, P. M. Monocular versus binocular vision in postural control. Auris Nasus Larynx, v. 31, n. 1, p. 11-17, 2004.

KRINSKI, K.; ELSANGEDY, H. M.; SOARES, I. A.; BUZZACHERA, C. F.; CAMPOS, W.; SILVA, S. G. Efeitos cardiovasculares agudos do exercício resistido em idosas hipertensas. Acta Scientiarum. Health Sciences, v. 30, n. 2, p. 107-112, 2008.

LOJUDICE, D. C.; LAPREGA, M. R.; GERDEZANI, P. M.; VIDAL, P. Equilíbrio e marcha de idosas residentes em instituições asilares no município de Catanduva, SP. Revista Brasileira de Geriatria e Gerontologia, v. 11, n. 2, p. 181-189, 2008.

MARFELL-JONES, M.; OLDS, T.; STEWART, A.; CARTER, L. International standards for anthropometric assessment. Potchefstroom: ISAK, 2006.

MAZO, G. Z.; LIPOSCKI, D. B.; ANANDA, C.; PREVÊ, D. Condições de saúde, incidência de quedas e nível de atividade física dos idosos. Revista Brasileira de Fisioterapia, v. 11, n. 5, p. 437-442, 2007.

MORAN, S.; CHEN, Y.; RUTHIE, A.; NIR, Y. Alterations in IGF-1 affect elderly: role of physical activity. European Review of Aging and Physical Activity, v. 4, n. 2, p. 77-84, 2007.

PEREIRA, I. C.; ABREU, F. M. C.; VITORETI, V. C.; LÍBERO, G. A. Perfil da autonomia funcional em idosos institucionalizados na cidade de Barbacena. Fitness and Performance Journal, v. 2, n. 5, p. 285-288, 2003.

PEREIRA, F. F.; MONTEIRO, N.; VALE, R. G. S.; GOMES, A. L. M.; NOVAES, J. S.; FARIA JUNIOR, A. G.; DANTAS, E. H. M. Efecto del entrenamiento de fuerza sobre la autonomía funcional en mujeres mayores sanas. Revista Española de Geriatría y Gerontología, v. 42, n. 6, p. 319-324, 2007.

QUADROS, T. M. B.; GORDIA, A. P.; SANTOS, I. C.; PASSONI, J.; CAMPOS, W.; VILELA JÚNIOR, G. G. Qualidade de vida de mulheres fisicamente ativas Acta Scientiarum. Health Sciences, v. 30, n. 1, p. 13-17, 2008.

RAMOS, L. R. Fatores determinantes do envelhecimento saudável em idosos residentes em centro urbano. Projeto Epidoso. Cadernos de Saúde Pública, v. 19, n. 3, p. 793-798, 2003.
RUBIO, R. M. A.; UREÑA, G. D.; RAVE, J. M. G.; SANTOS-GARCIA, D. J.; VALDIVIELSO, F. N. Efecto sobre la mejora y retención de la fuerza de un programa de entrenamiento de fuerza con cargas concentradas en sujetos no entrenados. Revista Internacional de Ciencias del Deporte, v. 7, n. 3, p. 24-33, 2007.

RUGELJ, D. The effect of functional balance training in frail nursing home residents. Archives of Gerontology and Geriatrics, v. 50, n. 2, p. 192-197, 2009.

SACCO, I. C. N.; BACARIN, T. A.; WATARI, R.; SUDA, E. Y.; CANETTIERI, M. G.; SOUZA, L. C.; OLIVEIRA, M. F.; SANTOS, S. Envelhecimento, atividade física, massa corporal e arco plantar longitudinal influenciam no equilíbrio funcional de idosos? Revista Brasileira de Educação Física e Esporte, v. 22, n. 3, p. 183-191, 2008.

SALMINEN, M.; VAHLBERG, T.; SIHVONEN, S.; SJOSTEN, N.; PIIRTOLA, M.; ISOAHO, R.; AARNIO, P.; KIVELA, S. L. Effects of risk-based multifactorial fall prevention on postural balance in the communitydwelling aged: A randomized controlled trial. Archives of Gerontology and Geriatrics, v. 48, n. 1, p. 22-27, 2009.

SILVA, J. G. B. F.; CADER, S. A.; DOPICO, X.; SOLER, E. I.; DANTAS, E. H. M. Fortalecimiento muscular, niveles de fuerza muscular y autonomía funcional en una población de mujeres mayores. Revista Española de Geriatría y Gerontología, v. 44, n. 5, p. 256-261, 2009. SPILÃ, S.; MULTANEN, J.; KALLINEN, M.; ERA, P.; SUOMINEN, H. Effects of strength and endurance training on isometric muscle strength and walking speed in elderly women. Acta Physiologica Scandinavica, v. 156, n. 4, p. 457-464, 1996

VALE, R. G. S. Avaliação da autonomia funcional. Fitness and Performance Journal, v. 4, n. 1, p. 4, 2005.

VALE, R. G. S.; NOVAES, J. S.; DANTAS, E. H. M. Efeitos do treinamento de força e de flexibilidade sobre a autonomia de mulheres senescentes. Revista Brasileira de Ciência e Movimento, v. 13, n. 2, p. 33-40, 2005.

VALE, R. G. S.; PERNAMBUCO, C. S.; NOVAES, J. S.; DANTAS, E. H. M. Teste de autonomia funcional: vestir e tirar uma camiseta (VTC). Revista Brasileira de Ciência e Movimento, v. 14, n. 3, p. 71-78, 2006 a.

VALE, R. G. S.; BARRETO, A. C. G.; NOVAES, J. S.; DANTAS, E. H. M. Efeitos do treinamento resistido na força máxima, na flexibilidade e na autonomia funcional de mulheres idosas. Revista Brasileira de Cineantropometria e Desempenho Humano, v. 8, n. 4, p. 52-58, 2006b.

VALE, R. G. S.; OLIVEIRA, R. D.; PERNAMBUCO, C. S.; MENESES, Y. P. S. F.; NOVAES, J. S.; ANDRADE, A. F. D. Effects of muscle strength and aerobic training on basal serum levels of IGF-1 and cortisol in elderly women. Archives of Gerontology and Geriatrics, v. 49, n. 3, p. 343-347, 2009.

WIACEK, M.; HAGNER, W.; HAGNERDERENGOWSKA, M.; BLUJ, B.; DROZD, M.; CZEREBA, J.; ZUBRZYCKI, I. Z. Correlations between 
postural stability and strength of lower body extremities of women population living in long-term care facilities. Archives of Gerontology and Geriatrics, v. 48, n. 3, p. 346-349, 2009.

WMA-World Medical Association. Declaration of Helsinki. Ethical Principles for Medical Research Involving Human Subjects. 59th ed. Seoul: WMA General Assembly, 2008.

ZAK, M.; SWINE, C.; GRODZICKI, T. Combined effects of functionally-oriented exercise regimens and nutritional supplementation on both the institutionalised and free-living frail elderly (double-blind, randomised clinical trial). BioMed Central Public Health, v. 9, n. 39, s/p., 2009.

Received on October 2, 2009.

Accepted on March 30, 2011.

License information: This is an open-access article distributed under the terms of the Creative Commons Attribution License, which permits unrestricted use, distribution, and reproduction in any medium, provided the original work is properly cited. 